\title{
Issues and Challenges in Financing the Poor: Lessons Learned from Islamic Microfinance Institutions
}

\author{
N. Satar and Dr. S. Kassim
}

\begin{abstract}
Islamic microfinance institutions (IMFIs) play a very important role in contributing towards higher financial inclusion among the poor, especially in the Muslim countries. Despite their importance, the IMFIs face wide ranging issues especially in the operational and regulatory aspects, and these issues hinder the effective development of the IMFIs. By examining the experience of two major IMFIs in Indonesia and Malaysia, namely Baitul Maal Wat Tamwil (BMT) and Amanah Ikhtiar Malaysia (AIM), this study offers a new perspective by making a comparative study between the two IMFIs with the aim of understanding the peculiarities facing each institution, unlike the earlier studies which commonly focusing on a particular institution only. The study finds that sustainability and human resource are the main issues facing both IMFIs. While structural issue such as reliance on subsidies could jeopardise the sustainability in the long run, human resource is highly critical in ensuring smooth functioning of the IMFIs as well as their sustainability even in the short run. Findings of this study contribute to highlight the critical factors to be emphasized in ensuring sustainability of IMFIs.
\end{abstract}

Keywords-component; microfinance, Baitul Maat Wat Tamwil (BMT), Amanah Ikhtiar Malaysia (AIM), Islamic finance

\section{INTRODUCTION}

Islamic microfinance plays a crucial role in improving financial inclusion among the poor especially in the Muslim nations by serving the financial needs of the poor who are commonly categorised as the "unbankables". In the South-east Asian region, Islamic microfinance has grown rapidly particularly in Indonesia and Malaysia, where the Muslimmajority populations have created a great demand for shari'ahcompliant microfinance products that can cater for the sociocultural peculiarities of the poor in these countries. The Islamic microfinance institutions (IMFIs) continue to expand their services to provide a variety of financial services to the poor segment of the community in the form of micro-credit, microsavings and micro-takaful. Efforts are continuously taken to integrate the Islamic third sector, namely zakat, waqf and sadaqah into the Islamic microfinance to help fully mobilise the financing capacity of Islamic social finance. In essence, the objective of Islamic microfinance is to fulfil the financial needs of the poor and as a means of poverty alleviation efforts to achieve equitable distribution of wealth and income with full adherence to the Islamic values.
Over time, this tool has become undoubtedly very effective in securing sustainable financing supporting the expanding needs for impact investment [1]. The "unbankables" require small amount of financial support over a period of time so that they can eventually break away from the poverty chain. The nature of IMFIs certainly fit into the financial requirements of this group of people as specific financial assistance can be structured with back-up trainings, follow-ups and consultations.

Different countries have different social structures and financial gaps among the citizens. Depending solely on the government via public spending to boost income is not always the only successful remedy. Therefore, tapping into Islamic social finance such as zakat and donations is the alternative that should be selected to combat poverty. Socially-related problems due to increased level of poverty can possibly be addressed by enterprises that focus on dual objectives of generating social impact and financial benefits [2]

Developing countries such as Malaysia and Indonesia that continuously strive to improve the socio-economic status of the less fortunate have creatively invented financial institutions to cater for the issues. It is worth looking into the two institutions to learn the good aspects that can be replicated and refined.

In Malaysia, Amanah Ikhtiar Malaysia (AIM) is the largest microfinance institution established in 1987 offering various micro financial services. Reflecting its commitment and excellence in the effort of alleviating poverty, AIM received "Best Microfinance Institution Award" from Global Islamic Finance Awards for four consecutive years from 2013 to 2016. This institution has been mandated to alleviate poverty and increase the household income under the Malaysian Economic Transformation Plan. Meanwhile in Indonesia, Baitul Maal Wat Tamwil (BMT) is one of the successful IMFIs that has grown significantly in numbers for the past twenty years and improved the lives of thousands of poor people in Indonesia.

Despite the success story, these two IMFIs face different internal and external issues in their operations. While AIM is established as a non-governmental organisation (NGO) receiving grant from the government, BMT is established as a cooperative and being more independent in terms of sources of funds. Being a private trust body mandated to reduce poverty, AIM has a clearer governance structure, thus has a more stable source of funds compared to BMT. Consequently, a number of 
BMTs have been shut-down due to financial problems. In view of the different models, if these two microfinance institutions were to be scrutinised, there are issues that are unique as well as common to both. This study aims to highlight the issues faced by AIM and BMT and discuss how the issues can be tackled by complementing the best practices of each IMFI. In comparing the issues and challenges facing AIM and BMT, greater emphasis is given to aspects that could possibly jeopardize the smooth running of their operations as well as the long-term survival of the institutions.

In this study, qualitative comparative analysis method is used with extensive article reviews. AIM and BMT are chosen because these two institutions are the leading examples of the IMFIs in the world and therefore, the issues that they are facing are of important interest to be shared so that relevant stakeholders are equipped with important input to make further improvement in the future.

\section{A REVIEW OF ISSUES FACED BY ISLAMIC MICROFINANCE INSTITUTIONS}

The noble intention of microfinance in improving the economic status of the unfortunate segment of the society needs no further introduction. Different microfinance institutions with different operating models and locations would naturally face different issues. In the context of AIM and BMT, despite their achievements in combating poverty, there are still some issues and challenges they face in providing financial access to the poor. This section discusses the issues and challenges faced by AIM and BMT in delivering the conscience-based financing services.

The success of BMT is dependent on determinants such as capability of financial management, characteristics of clients, capability of risk management, familiarity among clients and managerial team, and suitability of information technology (IT) and network. However, due to the nature of BMT being heterogeneous in its nature of operations, different locality will have different sets of determinants [3]. This renders the determinants to be very difficult to be generalized into standard forms and therefore, assessing the performance and effectiveness for comparisons between different BMTs is difficult. In actual practice, each BMT is given the liberty to run the institution given the peculiarities brought before them as well as the availability of resources that they have.

BMT is able to maintain its sustainability through the fund received from the social and religious collection, and the deposit from saving facilities offered by the institutions [4]. However, sometimes, BMT runs out of their deposit fund due to financing. Undoubtedly, fund raising is one of the core activities as reliance on the government for financial allocation is not possible. Dependency on social and religious collection on the other hand, hinges on the responsibility awareness of the surrounding communities; the more charity-minded people around could mean more funds coming in for financing activities.
To achieve sustainability from method other than religious collection, cash waqaf system is an ideal option [5]. The cash from donor is channelled to cash waqaf institution before being distributed to microentrepreneurs involved in a musyarakah mutanaqisah partnership. A slightly different model of cash waqaf for BMT was suggested by Ascarya and Sukmana [6] where it is suggested that the cash waqaf is managed by BMT so that income generation activities can be created, and subsequently more socially beneficial programmes can be funded. Through this way, the microfinance institution is expected to be more independent and have more ownership over their operations.

Internal factors such as lack of capital and innovation in marketing products, shortage of sources of funding, employees' underperformance, and facilities and technologies that are not up to date also affect the operational efficiency of BMTs [7]. Meanwhile, the external issues are stiff competition among the BMTs, low level of public trust towards BMT performance, lack of networking and co-operation among other financial institutions, as well as lack of supervision and guidance from government and Majlis Ulama Indonesia. However, despite the issues, BMT is still capable of connecting with the bottom of the economic group in the society [8].

On the other hand, AIM, being subsidized by the government, offers limited microfinance products and has standardized the lending contracts [9]. As of today, there are only three types of services offered, namely financing, compulsory savings and charity fund. More diversified products would enable customers to choose based on their needs and extend the deliverability of the objectives of AIM. For instance, products should be extended into using other Islamic contracts such as musyarakah (partnership) and ijarah (lease). Musyarakah in particular would encourage and drive the clients to work harder because of the profit and loss sharing element involved whereas simple loans really mimic the conventional method only. This contract gives honourship and higher sense of responsibility for the clients to execute their small scale business undertakings.

With the small financing given, many AIM clients utilise the financing to embark on small businesses, even though these clients are capable to self-employ. However, the income from the small businesses may not be higher than the wage income. There must be a way to further increase their income for them to graduate from the low wage especially for women clients who enjoy flexible hours so that they can manage their families at the same time [10].

\section{ISSUES AND CHALLENGES FACING THE IMFIS}

The issues and challenges facing both AIM and BMT in providing financial access to the poor can be divided into several categories. This section discusses these issues and challenges faced by AIM and BMT in delivering the conscience-based financing services. 


\section{A. Human Capital Performance}

The challenges of human capital performance in BMT come in several dimensions. Firstly, the staff lack spirits in developing Islamic financial services. In addition, there is insufficient human resources with good managerial skills to manage the performance of the institutions. Low understanding in economic principles and Islamic financial transaction aggravate the performance of the human capital. Shari'ah compliance is the key feature of doing business in Islamic microfinance but in practice, many officers and employees of BMT have low financial literacy. This situation is very upsetting because it will impact the perception of the community towards the image of BMT. The members of BMT are dependent on the institution to educate and support them in understanding and distinguishing between BMT and its conventional counterpart. When this issue with human resources are not addressed accordingly, people assume that financial products and services offered by BMT are similar with other conventional financial institutions. In reality, most of administrators and management of BMT also have no background in finance and economic.

According to the research conducted by Universitas Islam Indonesia, majority of BMT administrators lack knowledge and experience in managing Islamic finance institution, therefore in practice, BMT often deviate from Islamic principles and cannot be efficient in business management. In general, BMT started as a small business unit initiated by the public. Having a limited business scope with limited human resources capacity, human resource capability management skill in BMT has difficulty to grow. Due to budget constraint, human development training cannot be done that leads to the poor performance of human resources in BMT. This issue causes many BMTs to suffer bankruptcy problem because of operational failure [11]. Focusing on the case of BMT in Pekan Baru, the study supports that lack of quality human resource and absence of specific regulations affect its performance. The study also states most of employees in BMT do not have competency as shari'ah practitioners and do not have understanding about the concept of business [7].

Little or none has been written on AIM in terms of human resource performance based on the review carried out. This is a research gap that can be focused by future researchers. There seems to be many articles written on BMT which is applaudable because it shows that there are concerns with BMT and they want to see improvement due to the big potential that could benefit so many.

\section{B. Cost of Fund and Perception of Interest}

Cost of fund in BMT is higher than the cost of fund in Islamic and conventional banks. This is because BMT has to put in more effort to invite customers to save and deposit their fund in BMT by giving higher profit rate to depositor. At the same time, to offset that cost, BMT transfers the cost to other products which makes other products to cost more. This situation influences perception of the people that BMT is conducting financing scheme based on riba although BMT claim that they operate their product and service based on shari'ah principle [12].

It is understood that the basic of Islamic finance is the avoidance of riba. However, the perception of Indonesian Muslims on banking interest is still divided even though Majlis Ulama Indonesia has produced fatwa No. 1 in the year 2004 to forbid interest rate. It is important to note that the perception of Indonesian Muslims on interest is classified into three groups: a) interest is riba, thus it is haram, b) interest is halal as long as there is no Islamic bank, and c) interest is halal. This position restricts the opportunity of Islamic finance institution to make ordinary Muslims as their target market because of the different perception on interest [12].

In the case of AIM, there is zero cost of fund because financing is offered based on qard. However, a $10 \%$ service fee called ujrah is charged to the members. This rate is unusually high due to the unique operation of AIM and is suggested to be waived or kept to minimum to honour the spirit of qard hassan and offered to the hard core poor only [13]. Offering loan in the form of qard by charging service fee resembles conventional loan to the eye of the public. Therefore, AIM as an IMFI should consider introducing Islamic microfinance products based on equity based financing such as mudharabah and musharakah to the poor customers. By introducing Islamic microfinance products, AIM will not only become credit provider but more importantly, a business partner to its clients to foster their businesses and provide guidance to the clients to elevate themselves from the vicious chains of poverty

\section{Legal or Structural Problem and Standardization on Establishment and Operations}

To date, there is no specific act or regulation on BMT in Indonesia. The existence of BMT is based on Act of Cooperation and Ministerial Decree about KJKS (Koperasi Jasa Keuangan Syariah /Cooperation for Shari'ah Finance Services). This means that BMT is still governed by the conventional system. The Act of Cooperation only regulates cooperations in conventional structure. In Indonesia, Islamic banks are regulated by a specific act (Act. No. 21 Year 2008). There is no formal standardized regulation for BMT. This problem affects the stability of BMT presence because it gives opportunity for many "blind passengers" to manipulate the noble aims of BMT for their own interest such as accumulating wealth, getting higher benefit and misusing depositor fund for their own business. The conduct of the business of BMT become unethical and opposite to shari'ah and practical principle. Since there is no act, regulation or standardization for BMT's establishment and operation, fraud cases cannot be taken into court of law and punished. The consequence of their activity is that the reputation of BMT in the society is damaged and compromised [12].

There is also lack of legal support from government to BMT. Some of the issues are BMT in Indonesia is not governed by legal provisions and there is no suitable supervision and guidance system. This legal support issues become important considering the fact that BMT is the 
organization that administers and manages society's funds. Banks have deposit insurance agencies in the event of liquidation but BMT does not have this kind of support. The absence of a clear legal framework may also lead to the inaccessibility of deposit insurance agency. Thus, public savings collected by BMT is not properly protected [14].

AIM, on the other hand, is a private trust body that was established on 17 September 1987 and has been registered under Trust Act 1952 amendment 1981 (Act 258). The establishment of AIM is an effort of "Ikhtiar Project" which was a research project led by Professor David S. Gibbons and Professor Sukor Kassim [15]. As a registered private trust body, AIM is being governed by Lembaga Amanah Ikhtiar Malaysia mainly by the Board of trustee in which the membership consists of economic planning unit and implementation coordinator unit from the Prime Minister department, Ministry of Finance Malaysia, Ministry of Rural and Regional Development, state representatives and some other members that were appointed based on individual capacity.

The members of the Board of Trustee have the responsibility to ensure the administration, operation, distribution of fund and the implementation of project initiated for sahabat of AIM conducted with due diligence without any misappropriation. The operation of AIM is based on the mandate given by the government. In 2013, this institution was entrusted with RM 300 million to benefit over 500,000 borrowers by 2015 [16].

\section{Standardization of Shari'ah Supervisory Board Authors and Affiliations}

On the topic of the shari'ah compliance monitoring, Dewan Shari'ah Nasional Majlis Ulama Indonesia (DSN MUI) has appointed Shari'ah Supervisory Board (SSB) in each Islamic Financial Institutions (IFIs) representing DSN MUI to supervise and ensure that the IFIs operate according to Islamic principles. However, the presence of SSB in every IFIs does not make the general public feel reassured because people still see the gap between theory and practice. This could imply that, either the suggestions by SSB are not implemented or the general public does not really understand the shari'ah law to be able to discern the whole matter. Whatever it is, the responsibility lies with BMT to implement shari'ah law in their daily operations and ensure the general public are aware that they are implementing it.

BMT carried out standardization on three major aspects which are the standard operating procedures, human resources and financial statements. Even though SSB is an independent institution whose main function is to supervise compliance of shari'ah in the operations, IFIs need to be aware not to overlook compliance on Islamic principles s to avoid the risk of reputational damage. Research on BMT Yogyakarta found that BMT in general has implemented internal control, but there are still weaknesses in the authorization procedures. From 19 samples, only 11 BMT has SSB [17].
AIM has its own Shari'ah Advisory Board (Panel Penasihat Syari'ah) that carry out standardized supervision. This ensures homogeneity across the products and services offered. No sources are found to criticize or claim the functions of the advisory board of AIM so far.

\section{E. High Operating Cost and Reliance of Subsidy}

The Islamic microfinance providers face the issue of high operating costs in order to maintain financial sustainability. The cost of financing incurred by BMT is the same regardless of the size of the loans provided to the poor. Besides, high margin between the loan value and repayment reflects the problems of high transaction cost in loan processing. In addition, the issue of high cost will reduce financial inclusion. BMT, on average, distributes around US\$80-US\$400 in loan which is considered small. The administration cost that must be covered by BMT is around 50 percent from the nominal funding. This effectively means that, if there is no support in terms of subsidy for BMT, they must charge high margin to borrowers. Therefore, the role of subsidy is very important for BMT to ensure its sustainability. Reduction in transaction cost is a key issue that should be resolved for BMT in the long run. This issue is tricky due to the nature of the environment BMT is operating in. Offering financing to small entrepreneurs in rural areas in small amount can be very costly.

Subsidy has a direct influence on microfinance. Subsidized lending will have a positive impact on reducing financing rate or margin especially in BMT. Many BMTs search for private donors because the administration is easier than public subsidies. The problem that occurs in BMTs is that many BMTs can only sustain in the first two years without subsidy. After that, many of them collapse. External subsidy is crucial especially for the small-sized BMTs. Maintaining BMT performance by maintaining subsidy stability is a challenge for BMT. The government, national private companies and international donors have to keep providing subsidized financing sources for the poor using BMT and the importance of subsidy is unquestionable [4]. Customers prefers Islamic bank financing because of the steadier and more stable flow of fund compared to BMT. Increasing asset and drastic liability mismatch lead liquidity risk and the less resilient BMT is prone to external shocks [6].

Delegated with the task of alleviating poverty in Malaysia, AIM receives strong financial and non-financial support from the Malaysian government and its agencies, which is critical to its sustainability. Financial support comes in the form of interest-free government financing, grants and soft loans through allocations made under various Malaysia Plans. Similar to conventional microfinance institutions, AIM unavoidably experience high transaction costs due to asymmetric information problems. These costs relate to monitoring and searching costs and the cost of administration, which are all directly associated with the information problems in the rural financial markets. Small loans are expensive because of high overhead costs, which usually have a large 
fixed cost attached. AIM must find a mechanism to reduce transaction costs as added costs are often passed onto clients.

AIM still depends heavily on the support from the government and related agencies for funding. The operational cost of AIM is relatively high and salaries and administrative cost from the major proportion of operation cost, nevertheless creating only a small portion of assets. By means of a fixed administrative charge of $10 \%$, it does not cover its operating costs and could not be sustainable and self-dependent. AIM should look again on their fundamental principles because of the loss of direction in focusing on the not so poor or non-poor and giving larger loans and better-off borrowers. Therefore, there is no incentive from such institutions to offer any other microfinance products apart from microcredit loans to finance their operation. This theory also occurred in BMT which many of them searching for private donor because the administration is easier than public subsidies as mentioned earlier [18]. If costs are not covered, the capital will be depleted and continued access to financial services will be difficult. Therefore, AIM should seek financial funding from variety sources other than government to maintain their sustainability in the long-term.

\section{F. Repayment Problem Among Members}

Geographical distance is important because it will lead to Islamic microfinance efficiency. The higher distance will cause more credit rationing problem. One of the features for the people at the bottom of the economic pyramid is that, they live in remote areas which are far away from financial institutions including BMT. People who live near to BMTs have lower incidence of credit rationing and one of the difficulties facing the poor borrowers in accessing credit is the distance between their homes and the BMTs. In practice, BMTs need to include the distance between the BMTs and the borrower to help in deciding whether they should get financing or not. This is because short distance will make the monitoring process easier and the application would have a greater chance of being approved. The distance of a borrower's house from BMT is also a determinant of credit rationing. Financial services nearness is described as poor people who live nearer to microfinance institutions and can be contacted. People who live closer to BMT will have easier access to financing since it will reduce the cost of monitoring because it does not require BMT staff to take public transportation that would acquire a cost. A greater risk will be faced by BMT if they give funding to far away borrowers [4].

Furthermore, the long travel time from home to BMT cause customers to get less access to information and updates. It also makes the frequency of customers' meetings with BMT employees getting smaller so the chances of bad repayment rate increase and also smaller participation of the customer of BMT to borrowing. For example, in BMT Khairu Ummah located on Jalan Raya Leuwiliang, Leuwiliang, Kabupaten Bogor, as well as two branches of BMT Khairu Ummah located in the Cigudeg and Puraseda Village, Leuwiliang have a bad repayment rate and one of the reason are the customers' home are far away from the BMT agency [19].

AIM members also have repayment issue but the cause of the issue is different and related to client selection procedure of AIM that starts with measuring potential clients' average monthly household income. Households with average monthly household income below the Poverty Line Income (PLI) has been calculated by the Malaysian government since the year 1976. It was estimated based on the necessity of food and other basic needs and would be considered as absolute poor, while households with average monthly household income below half of the PLI would be categorized as hardcore poor. Therefore, households whose average monthly household income falls below the PLI, including both poor and hardcore poor households, are considered to be eligible to obtain microcredit from AIM.

Based on a survey in Kelantan, Terengganu and Kedah, more than $50 \%$ of the total respondents reported that they used credit in non-income generating activities, which increases the chance of encountering repayment problem. Repayment problems can lead clients to leave the program or become inactive borrowers. When hardcore poor households' income streams are interrupted, which is commonly the case, the clients may have to sell their fixed assets to repay the loan. AIM therefore has to consider a flexible loan policy to allow poor and hardcore poor households to reorganize the loan when clients encounter any financial crisis. AIM should also focus on appropriate training and development programs in order to enable the hardcore poor households to use credit in income generating activities, grasp employment generating opportunities as well as find and invest in new income generating activities, which eventually reduce their repayment problem [20].

\section{G. Lack of Business Knowledge and Technical Skills}

BMT is faced with the lack of entrepreneurial development in the community [14]. When potential members do not have the skill to run a business, upward social mobility cannot be achieved in the event of the members fail. The lack of exposure and education also contribute to the non-delivery of the financing granted with the intention to assist the poor to increase their income. PBMT Institute is one initiative to provide training program related to managerial aspect of BMT in order to produce competent and high quality staff and deal with human resources problem. However, not many BMTs are interested to send their staff for the programme since it requires some fee payment [21].

In the Malaysian environment, entrepreneurship culture does not blend well amongst the Malays and Bumiputera as compared to the Chinese. For Chinese, most of their businesses succeed and they transfer down their skills through generations. Hence, knowledge in business management and related technical skills have to be transferred to all microfinance borrowers since majority of them are Malays and Bumiputera. Realizing this issue, AIM provides business and financial management course to the borrowers but only 
selected borrowers are chosen to attend the course. AIM also does not have a standardized module of training specially to handle different level of borrowers. For example, the level of understanding financial and business management topics may vary from each borrower. The trainer or the speaker needs to make it easy and simple for the information and knowledge to be understood because the audiences lack education.

Based on the research, many AIM borrowers lack knowledge on how to manage their business income. Most of them do not know how to separate between their business and personal consumption. Many borrowers allocate a large portion of their income for personal consumption and only the least amount for their businesses. Many use the income to financially support their daily living expenses and make little effort to expand their businesses. This is one of the many reasons, why some of their businesses are unsuccessful even after continuous microcredit loans. The major constraints for the poor have always been the dependency on a single economic activity and the lack of skills to vary their sources of income to supplement their daily living [22]. The success of microfinance depends largely on the skills and understanding of the people managing the microfinance programme given the unbankable nature of microfinance clients themselves, namely low literacy level, having little knowledge about business, and having no physical assets.

\section{CONCLUSION}

Facing different operating situations and unique peculiarities, both AIM and BMT have their own shortfalls. They have almost similar categories of issues, being formed having the objective of poverty alleviation, most issues stem from criteria of the members as well as the staff of the institutions. Members with no background in business and IMF staff with no shari'ah training and exposure are among the most serious potential factors for failure. Therefore, human capital, from the members and the IMFs, play pivotal role in ensuring the success of the social financing.

Another glaring issue is the reliance on subsidies of AIM and dependency on donors by BMT. Inevitably, the nature of profit maximization is not the modus operandi, hence, these IMFs need to find other source of funding such as SRI sukuk that has been gaining ground over the recent years. This can be further looked into in future research.

While AIM is blessed with the support from the government, the BMT lacks this legal support. Some amendment to the laws pertaining IMFs would accommodate their growth. Shari'ah issue is not seen as a stumbling block for the operations of AIM but for BMT, it is more serious. The role of shari'ah supervisory board is still minimal and the mixed perception of the Indonesian public on riba puts restriction for BMT to widen its market.

Between the two institutions, credit is due to BMT for its non-dependency on government grant for source of funds.
BMT fits the description of IMFIs that can stand on its feet to offer financing to the poor without the government having to dig deeper into their coffers. They actually help the government by serving the customers who are unbankable and live in different types of difficult geographical settings that cannot be reached by the normal financial institutions.

In summary, internal issues can be managed by the IMFs and government but external issues that concerns the mindset of the members need intervention from more parties. BMTs issues are more complex to be solved because of the nonstandardization elements in the operations as compared to AIM. A special task force looking into each and every BMT for improvement is ideal but difficult to be executed due to its heterogeneity and resources to fund the task force.

\section{REFERENCES}

[1] Biancone, P. Pietro, \& Radwan, M. (2018). Social Finance And Unconventional Financing Alternatives: An Overview. European Journal of Islamic Finance,, (10), 1-6. https://doi.org/10.13135/2421-2172/2818

[2] Biancone, P. Pietro, \& Radwan, M. (2019). Social Finance and Financing Social Enterprises: An Islamic Finance Prospective. European Journal of Islamic Finance, 0(0). https://doi.org/10.13135/24212172/3176

[3] Hosen, M. N., \& Sa 'roni, L. S. (2012). Determinant Factors of the Successful of Baitul Maal Wat Tamwil (Bmt). International Journal of Academic Research in Economics and Management Sciences, 1(4), 2226-3624. Retrieved from www.hrmars.com/journals

[4] Wulandari, P., \& Kassim, S. (2016). Issues and challenges in financing the poor: case of Baitul Maal Wa Tamwil in Indonesia, International Journal of Bank Marketing, Vol. 34 Issue: 2, pp. 216-234

[5] Asmy, M., Mohammed, M. O., \& Abdullah, M. A. (2016). Developing cash waqf model as an alternative source of financing for micro enterprises in Malaysia Article information. Journal of Islamic Accounting and Business Research, 7(4), 254-267. Retrieved from www.emeraldinsight.com

[6] Ascrya, A., \& Sukmana, R. (2017). Cash Waqf Models of Baitul Maal wat Tamwil in Indonesia. In International Conference and Call for Paper: Waqf and Economic Growth

[7] Hamzah, Rusby, Z., \& Hamzah, Z. (2013). Analysis Problem of Baitul Maal Wat Tamwil (BMT) Operation in Pekanbaru Indonesia Using Analytical Network Process (ANP) Approach. International Journal of Academic Research in Business and Social Sciences, 3(8), 215-229. https://doi.org/10.6007/IJARBSS/v3-i8/138

[8] Possumah, B. T., \& Baharuddin, G. (2012). Governing Baitul Mal towards 2020; Issues and Challenges: Indonesia Experiences. International Journal of Business and Management Tomorrow, 2(10), 110. Retrieved from www.ijbmt.com

[9] Mokhtar, S. H., Nartea, G., \& Gan, C. (2012). The Malaysian Microfinance System and A Comparison With the Grameen Bank (Bangladesh) and Bank Perkreditan Rakyat (BPR-Indonesia). Journal of Arts and Humanities, 1(3), 1-18

[10] Al- Mamun, A.-, Abdul Wahab, S., \& Malarvizhi, C. A. (2011). Examining the Effect of Microcredit on Employment in Peninsular Malaysia. Journal of Sustainable Development, 4(2), 174-183. https://doi.org/10.5539/jsd.v4n2p174

[11] Nurasyiah, A., Utami, S. A., \& Mahri, A. J. W. (2016). The Challenges of Human Capital Performance in Developing Baitul Maal Wat Tamwil in Indonesia, 15, 599-604

[12] Kholis, N. (2012). The Prospect of Islamic Microfinance Institutions in Indonesia. Episteme, 7

[13] Saad, N. M. (2012). Microfinance and Prospect for Islamic Microfinance Products: The Case of Amanah Ikhtiar Malaysia. Advances in Social 
Science,1(1). $\quad$ Retrieved from http://irep.iium.edu.my/27269/1/Possible_Islamic_Products_for_Microcr edit_Scheme.pdf

[14] Rusydiana, A. S., \& Devi, A. (2013b). Challenges In Developing Baitul Maal Wat Tamwiil (BMT) In Indonesia Using Analytic Network Process (ANP). Business and Management Quarterly Review, 4(2), 5162. Retrieved from https://core.ac.uk/download/pdf/83283333.pdf

[15] https://www.aim.gov.my/maklumat-korporat-aim

[16] http://edbizconsulting.com/publications/ISFIRE 11 2013.pdf

[17] Mediawati, E., \& Agustami, S. (2016). Sharia Compliance on Murabaha Financing. Advances in Economics, Business and Management Research, 15, 161-162

[18] Abdul Rahman, R., \& Dean, F. (2013). Challenges and solutions in Islamic microfinance. Humanomics, 29(4), 293-306. https://doi.org/10.1108/H-06-2012-0013

[19] Effendi, J., \& Utami, A. R. (2016). The Effect of Social Capital on Customer's Repayment Rate at Islamic Microfinance Institution. AlIqtishad: Journal of Islamic Economics, 8(2), 227-242. https://doi.org/10.15408/aiq.v8i2.2631

[20] Abdul Wahab, S., Al- Mamun, A.-, Malarvizhi, C. a., \& Mariapun, S. (2011). Examining the Critical Factors Affecting the Repayment of Microcredit Schemes in Amanah Ikhtiar Malaysia (AIM) in Malaysia. International Business Research, 4(2), 93-102. https://doi.org/10.5539/ibr.v4n2p93

[21] PBMT. (2015). Haluan BMT 2020 BMT sebagai Sokoguru Perekonomian Indonesia

[22] Mason, C., Wan Azmi, W. N., \& Madden, R. (2015). Aiming for Greater Financial Inclusion through Sustainable Development: The Story of AIM (Amanah Ikhtiar Malaysia) 


\title{
Editor in Chief
}

\author{
Prof. Paolo Pietro Biancone, \\ University of Turin, Italy
}

\section{Editorial Board}

Prof. Dian Masyita, University of Padjadjaran, Indonesia

Prof. Abtulazeem Abozaid, Qatar Faculty of Islamic Studies, Qatar

Prof. Ahmod Aref Almazari, King Sand Universiry, Saudi Arabia

Prof. Bashar Malkawi, Universiry of Sharjah, UAE

Prof. Marco Meneguzo, Universiti degli Studi di Roma "Tor Vergata", Inaly

Prof. Buerhan Saiti, Istanbul Sabahattin Zaim University, Turkey

Prof. Nidal A Alsayyed, Inayah Islamic Finance Research Institute, USA

Prof. Roberta Aluffi, University of Turin, Italy

Prof. Ghasen Bouslama, NEOMA Business School, Campus de Reims, France

Prof. Nazam Dzolkamaini, Salford University, UK.

Prof Kabir Hassan, University of New Orleans, USA

Prof Fhaled Hussainey, Universiry of Portsmouth, UK

Prof. Rifki Ismal, Universiry of Indonesia

Prof. Tariqullah Khan, Hamad bin Khalifa University, Qatar

Prof. Ali Khorshid, ICMA Centre Reading Universiry, UK.

Prof. Amir Kin, Utah Valley Universiry, USA

Prof. Laurent Marliere, Université Paris-Dauphine, France

Prof. Federica Miglienta, University of Bari, Italy

Phof. Hakim Ben Othman, Universiry of Tunis, Tunisia

Prof. Mohamed Ramody, King Fahd University of Petroleum and Minerals, Saudi.Arabia

Prof. Mamumur Rashid, Nottingham University, Malaysia

Prof. Yomes Soualhi, International Islamic University, Malaysia

Prof. Laurent Weill, University of Strasbourg. France 